\title{
The Role of Customer Satisfaction in Mediation the Effect of Customer Relationship Management on Customer Loyalty (Study at Ramayana Bali Department Store Denpasar)
}

\author{
Kadek Dian Nita Grihani and Ni Made Wulandari Kusumadewi
}

\section{ABSTRACT}

\begin{abstract}
This study aims to analyze the effect of leadership style, work environment on employee retention with non-physical work environment as a moderating variable. The research design used is associative. The research was conducted at Ayodya Resort Bali. The population of this study was 501 employees with 84 employees as samples. The sample selection technique is proportional stratified. The data collection method used is Observation, Interview, Questionnaire and analyzed by Moderated Regression Analysis (MRA). The results show that leadership style has a positive and significant effect on employee retention, the better the leadership style applied by the company, the employee's desire to remain in the company will also increase. The non-physical work environment strengthens the influence of leadership style on employee retention, the better the leadership style supported by a good non-physical work environment, the employee's desire to remain in the company will increase. Companies must always pay attention to the relationship between employees and the relationship between employees and superiors so that they continue to run well and harmoniously.
\end{abstract}

Keywords: customer loyalty, customer satisfaction, customer relationship management.

\section{INTRODUCTION}

Economic growth and people's purchasing power make the current spending patterns of Indonesian people change and develop as a reflection of a more modern lifestyle. Indonesian people are starting to switch to modern retail compared to traditional markets which has led to the development of the modern retail business. Retail trade is a business activity that involves selling goods or services directly to final consumers for personal and non-business use. The retail business is part of the distribution channel that connects the interests of producers and consumers (Suwandy \& Setyari, 2020).

Competition due to the existence of various kinds of modern retail not only creates opportunities but also poses challenges as well as threats to business actors to maintain business continuity. The increasingly fierce level of business competition has resulted in many companies no longer focusing their marketing activities solely on finding new buyers, but instead on efforts to maintain and increase the loyalty of old customers. Attracting new customers costs five times more than it costs to retain and satisfy existing customers. Customers who survive or are often referred to as retained customers will be happy to reveal positive things and provide recommendations about the company to others, indirectly retained customers play an important role in the formation of loyalty to the company (Kotler \& Keller, 2016).
Customer loyalty is the most important thing for the sustainability of retail companies in competitive competition and is an important component of the growth and performance of retail companies. Companies must design customer-driven marketing strategies and build the right relationships with the right customers to maintain customer loyalty (Assegaff \& Pranoto, 2020).

Customer Relationship Management is a strategy that focuses on creating customer satisfaction and long-term relationships by integrating several functional areas of the company to gain competitive advantage. Companies that implement a Customer Relationship Management system to manage detailed information about individual customers and carefully manage "customer touch points" to maximize loyalty(Kotler \& Keller, 2016). Customer Relationship Management serves to understand customers better so that companies can provide a higher level of customer service and develop deeper customer relationships.

Customer Relationship Management is a service approach to consumers that focuses on building long-term and sustainable customer relationships that can provide added value to customers. The goal is to provide satisfaction for its customers. Customer satisfaction or customer satisfaction is a person's feeling of pleasure or disappointment arising from comparing the perceived performance of a product or service to his expectations (Ibrahim \& Amatullah, 2018). The implementation of Customer Relationship Management has a 
significant effect on customer loyalty. The success of a company in building loyalty is generally influenced by customer satisfaction (Setyaleksana et al., 2017).

PT Ramayana Lestari Sentosa Tbk or known as Ramayana is a company engaged in the retail trade business as one of the leading department stores in Indonesia. Ramayana provides the daily needs of the lower middle class. Ramayana is determined to provide a wide range of products at reasonable and affordable prices with friendly and courteous customer service. The number of retail industries in Denpasar makes the competition even tougher. The competition in the retail industry in Denpasar forces Ramayana to maintain its existence, thereby creating customer loyalty, therefore Ramayana implements member cards and loyalty programs as an effort to maintain its relationship with customers. Loyalty program is implemented by retailers in an effort to increase customer loyalty by offering various service facilities that are considered attractive to customers. Ramayana Department Store also implements a customer service system which is implemented by providing a suggestion box and a contact that customers can contact to express their hopes, criticisms or suggestions for future improvement of the company (Afifah, 2017).

As for some research gaps found in previous studies. Pemayun \& Seminari (2020) found that customer satisfaction has a positive role on customer loyalty (Pemayun \& Seminari, 2020). But different from Tanisah \& Maftukhah (2016) who found that customer satisfaction had no effect on customer loyalty. In the Customer Relationship Management variable (Tanisah \& Maftukhah, 2016), there are differences where Yudhanta \& Widodo (2018) who conducted research on Smartphone users suggested that Customer Relationship Management has an influence on customer loyalty (Yudhanta \& Widodo, 2018). Whereas Khairawati (2020) found that Customer Relationship Management has no significant effect on customer loyalty (Khairawati, 2020).

\section{LITERATURE REVIEW}

Customer Relationship Management has a positive and significant effect on satisfaction (Laksmana et al., 2018). The company uses Customer Relationship Management as capital to make customers more satisfied. This study concludes that Customer Relationship Management plays a major role in increasing customer satisfaction and in-depth customer knowledge of customers. Better Customer Relationship Management will have clear information about what customers want, what their needs are, and what makes them more satisfied (Siddiqi et al., 2018; Felix, 2016).

H1: Customer relationship management has a positive and significant effect on customer satisfaction

Customer Relationship Management has a significant positive effect on customer loyalty where customers as a source of profit for the company, will be very good at retaining existing customers while looking for new customers. Good customer relationship management can make you stay with the company (Harryani, 2017; Salah \& Abou-Shouk, 2019).

$\mathrm{H} 2$ : Customer relationship management has a positive and significant effect on customer loyalty.
The success of the retail business lies in the satisfaction felt by customers in shopping at retail places. The right indicator to conduct research in the retail business is customer loyalty because the satisfaction felt by customers will create customer loyal behavior. According to previous research, customer satisfaction has a positive effect on customer loyalty (Utami \& Ekawati, 2020; Setyaleksana et al., 2017; Pemayun \& Seminari, 2020).

H3: Customer satisfaction has a positive and significant effect on customer loyalty

Customer Relationship Management plays a major role in increasing customer satisfaction which then has an impact on increasing customer loyalty (Hassan et al., 2016). customer loyalty is influenced by Customer Relationship Management with customer satisfaction as the connecting variable. One way that can be done to keep consumers is to make consumers feel satisfied. Consumer satisfaction is obtained through the fulfillment of consumer needs and desires. To find out what consumers need and want, companies must establish relationships with consumers. So, customer relationship management is a strategy that companies need to optimize profits by increasing customer satisfaction. If the customer is satisfied, then the customer will have loyalty to the bank. The successful implementation of the Customer Relationship Management strategy will increase customer satisfaction and customer loyalty (Harryani, 2017).

H4: Customer satisfaction mediates the effect of customer relationship management on customer loyalty.

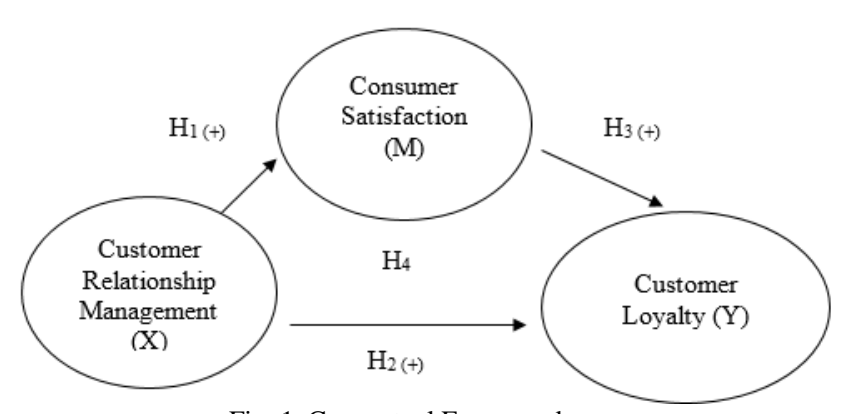

Fig. 1. Conceptual Framework.

\section{Methodology}

This research uses quantitative approach method with associative type. Quantitative research is systematic scientific research on parts and phenomena and their relationships. This study discusses the influence of Customer Relationship Management on customer satisfaction, the influence of Customer Relationship Management on customer loyalty, the effect of customer satisfaction on customer loyalty, and the role of customer satisfaction in mediating Customer Relationship Management on customer loyalty.

The research location was conducted at the Ramayana Bali Department Store Denpasar. The considerations made to choose Ramayana Bali Department Store Denpasar as the research location are because there are indications of low customer loyalty based on the decline in sales in the financial statements in 2020. The object of this research is consumer behavior, especially customer loyalty that arises as a result of Customer Relationship Management, customer satisfaction. and customer loyalty to the service of Ramayana Bali Department Store Denpasar the exogenous variable in this 
study is Customer Relationship Management which is symbolized by $\mathrm{X}$. The mediating variable is a variable that plays a dual role and bridges the relationship between exogenous and endogenous variables. The mediating variable in this study is customer satisfaction which is symbolized by $\mathrm{M}$. The endogenous variable in this study is customer loyalty which is symbolized by $\mathrm{Y}$.

Quantitative data in this study is in the form of customer age data, total sales of Ramayana Bali Department Store Denpasar 2015-2020 period. The qualitative data in this study are the answers to the questionnaires given to the respondents. Primary sources are respondents who provide data through questionnaires that have been distributed. Secondary sources are sources of data obtained from the results of previous studies that have been collected by people other than researchers. The secondary sources used are information from the internet, books and journals related to the discussion of the problem.

This study used a questionnaire as a measuring tool. To find out whether the questionnaire is feasible or not, it is necessary to test the validity and reliability. The questionnaire consists of open and closed statements. Open statements include the respondent's name, age, gender, and respondent's occupation. Closed statements are statements that have been and are given a choice of answers. Closed statements will be measured using a Likert scale with a scale of 1 to 5. This scale measures a person's opinions and perceptions about social events or phenomena.

The population of this study is consumers who have shopped at the Ramayan Department Store Denpasar, where the size of the population of this study is unknown or unlimited. The number of indicators used in this study is 11 indicators, so the sample size is in the range of 55-110. Based on these considerations, the sample size in this study was set at 110 respondents. This study uses a non-probability sampling method, namely purposive sampling with predetermined criteria, namely a minimum high school education and having shopped at the Ramayana Bali Department Store Denpasar in the last 3 months, this consideration is used so that consumers still remember the Customer Relationship Management treatment applied at Ramayana. Bali Department Store Denpasar. The number of samples was 110 respondents with the research instrument in the form of a questionnaire. Researchers distributed questionnaires directly to people who had shopped at Ramayana Bali Department Store Denpasar".

\section{RESULTS}

\section{A. Effect of Customer Relationship Management on Customer Satisfaction}

The t-count value is 6.920 and the t-test significant value is $0.000<0.05$, it can be concluded that Customer Relationship Management has a positive and significant effect on customer satisfaction. This shows that the company makes Customer Relationship Management a capital to make customers more satisfied. This study concludes that Customer Relationship Management plays a major role in increasing customer satisfaction and in-depth customer knowledge of customers. Better Customer Relationship Management will have clear information about what customers want, what their needs are, and what makes them more satisfied.

TABLE I: SUMMARY OF PATH ANALYSIS RESULTS

\begin{tabular}{|c|c|c|c|c|c|}
\hline \multicolumn{6}{|c|}{ Substructure 1} \\
\hline & \multirow{2}{*}{ B } & \multirow{2}{*}{$\begin{array}{l}\text { Std } \\
\text { Error }\end{array}$} & \multirow{2}{*}{ Beta } & \multicolumn{2}{|c|}{$\mathrm{t}$ value } \\
\hline & & & & $\mathrm{t}_{\text {count }}$ & Sig. \\
\hline (Constant) & 4.746 & 1.095 & \multirow{5}{*}{$\begin{array}{c}0.554 \\
0.307 \\
47.880 \\
0.000 \\
\end{array}$} & 4.333 & 0.000 \\
\hline CRM & 0.438 & 0.063 & & 6.920 & 0.000 \\
\hline R Square & & & & & \\
\hline $\mathrm{F}$ & & & & & \\
\hline Sig. & & & & & \\
\hline \multicolumn{6}{|c|}{ Substructure 2} \\
\hline & \multirow{2}{*}{ B } & Std & \multirow{2}{*}{ Beta } & \multicolumn{2}{|c|}{$\mathrm{t}$ value } \\
\hline & & Error & & $\mathrm{t}_{\text {count }}$ & Sig \\
\hline (Constant) & 7.195 & 1.459 & & 4.933 & 0.000 \\
\hline CRM & 0.192 & 0.093 & 0.204 & 2.056 & 0.042 \\
\hline $\begin{array}{l}\text { Customer } \\
\text { satisfaction }\end{array}$ & 0.448 & 0.118 & 0.376 & 3.790 & 0.000 \\
\hline R Square & \multicolumn{5}{|c|}{0.269} \\
\hline $\mathrm{F}$ & \multicolumn{5}{|c|}{19.653} \\
\hline Sig. & \multicolumn{5}{|c|}{0.000} \\
\hline \multicolumn{6}{|c|}{$\mathrm{t}=\frac{\mathrm{ab}}{\mathrm{Sab}}=\frac{(0.554)(0.376)}{0.078}=\frac{0.2083}{0.075}=2.777$} \\
\hline
\end{tabular}

\section{B. Effect of Customer Relationship Management on Customer Loyalty}

The t-count value is 2.056 and the t-test significant value is $0.042<0.05$, it can be concluded that Customer Relationship Management has a positive and significant effect on customer loyalty. This shows that Customer Relationship Management is one of the business approaches based on relationship management or relationship with customers. Customer Relationship Management focuses more on what customer's value, not on the products the company wants to sell. Through the implementation of Customer Relationship Management, the company is expected to be able to build good communication and relationships with its consumers so that in producing a product the company does not only sell and market a product with good quality or competitive prices but also can answer the wants and needs of consumers. With the fulfillment of needs, desires appropriately can encourage the creation of a customer loyalty, so that consumers will automatically come back again to buy and consume these products. Companies are required to be able to provide the best service to their customers. Companies are required to be able to understand what their customers want. Customer Relationship Management is a tool in communication, customers basically want to be treated differently, because satisfactory service will make customers loyal. The essence of Customer Relationship Management is not only serving, but because the company has customer data, the company must serve it better, so that customers will become loyal.

\section{The Effect of Customer Satisfaction on Customer Loyalty}

The $\mathrm{t}$-count value is 3.790 and the t-test significant value is $0.000<0.05$, it can be concluded that customer satisfaction directly has a positive and significant effect on customer loyalty. This shows that the success of a company in building loyalty is generally influenced by customer satisfaction. In the long term, satisfaction will have an impact on the formation of customer loyalty. When customers are satisfied with the products or services provided by a company, 
customers will tend to re-purchase the product or visit the service where this is one indicator of the emergence of customer loyalty. Progress in the business world requires companies to be able to make customers feel satisfied because if the customer is satisfied, the customer will automatically become loyal to the company.

D. The Effect of Customer satisfaction in Mediating the Influence of Customer Relationship Management on Customer Loyalty

The value of t_count is 2.777 while t_table at 0.05 significance is 1.96 so that $t$ _count $>t$ table $(2.777>1.96)$. Based on the results of the analysis above, it can be concluded that customer satisfaction is able to mediate the influence of Customer Relationship Management on customer loyalty. This shows that one way that can be done to keep consumers is to make consumers feel satisfied. Consumer satisfaction is obtained through the fulfillment of consumer needs and desires. To find out what consumers need and want, companies must establish relationships with consumers. So, customer relationship management is a strategy that companies need to optimize profits by increasing customer satisfaction. If the customer is satisfied, they will have loyalty to the Ramayana Bali Department Store Denpasar. The successful implementation of the Customer Relationship Management strategy will increase customer satisfaction and customer loyalty.

\section{E. Implication}

Based on the results of the research conducted, it shows that this study has been able to confirm several previous studies, as well as strengthen previous research on the role of customer satisfaction in mediating the influence of customer relationship management on customer loyalty. The results of this study are expected to be used as input for Ramayana Bali Department Store Denpasar, so as to increase customer loyalty. Based on the results of the study, customer satisfaction besides being able to directly influence positively on the creation of customer loyalty can also be said to be a variable that can mediate the influence of customer relationship management on customer loyalty. In accordance with the results of this study, indicators that can still be improved by Ramayana Bali Department Store Denpasar are promotions and special offers such as discounts and also employee service as a strategy to increase customer retention.

\section{F. Research Limitations}

Based on the research that has been done, several limitations were found in this study. This research is only limited to customer relationship management variables and customer satisfaction in influencing customer loyalty and the scope of the research area is only at the Ramayana Bali Department Store Denpasar so that the results of this study cannot be generalized. In addition, this study uses crosssectional data collection so that it can lead to different results if there are similar studies at different times and places.

\section{CONCLUSION}

Customer Relationship Management has a positive effect on customer satisfaction. This shows that better Customer Relationship Management will have clear information about what customers want, what their needs are, and what makes them more satisfied. Customer Relationship Management has a positive effect on customer loyalty. This shows that the core of Customer Relationship Management is not only serving, but because the company has consumer data, the company must serve better, so that customers will become loyal. Customer satisfaction has a positive effect on customer loyalty. This shows that customer satisfaction is an important factor in creating loyalty, by feeling satisfied with a product, consumers will automatically come back to buy and consume the product. Customer satisfaction is able to mediate the influence of Customer Relationship Management on customer loyalty. This shows that Customer Relationship Management plays a major role in increasing customer satisfaction which then has an impact on increasing customer loyalty.

Companies need to promote their products according to the actual state of the product, so as not to disappoint customers. Company leaders need to improve the quality of the products offered, so as not to cause disappointment to customers and maintain consumer confidence in order to retain consumers.

\section{REFERENCES}

Afifah, P. (2017). Strategi mempertahankan pelayanan dan kesetiaan pelanggan pada industri ritel menurut ekonomi Islam (Studi Pada Pengusaha Ritel Modern Sumber Alfaria Trijaya Tbk Di Lampung Timur). Jurnal Ekonomi Syariah, 1(1), 1.

Assegaff, S. B., \& Pranoto, S. O. (2020). Price Determines Customer Loyalty in Ride-Hailing Services . American Journal of Humanities and Social Sciences Research (AJHSSR), 4(3), 453-463.

Felix, R. (2016). Pengaruh Customer Relationship terhadap Loyalitas Pelanggan Tivoli Club House Sidoarjo dengan Kepuasan Pelanggan sebagai Variabel Perantara. Jurnal Hospitality Dan Manajemen Jasa, $4(1), 406-421$.

Harryani, S. (2017). Customer Relationship Management Influence on Customer Value, Product Quality and Service Quality in Improving Customer Satisfaction and Its Implication on the Customer Loyalty. Jurnal Ilmiah Ekonomi Bisnis, 22(2), 178575.

Hassan, R. S., Nawaz, A., Lashari, M. N., \& Zafar, F. (2016). Effect of Customer Relationship Management on Customer Satisfaction. $\begin{array}{lll}\text { Economics and } & \text { Finance, 23(10), } & 563-567 .\end{array}$ https://doi.org/10.1016/s2212-5671(15)00513-4.

Ibrahim, A., \& Amatullah, S. (2018). Implementing Customer Relationship Management to Increase Education Service using Service Quality Method. Journal of Information Systems Engineering and Business Intelligence, 4(2), 148. https://doi.org/10.20473/jisebi.4.2.148-155.

Khairawati, S. (2020). Effect of customer loyalty program on customer satisfaction and its impact on customer loyalty. International journal of research in business and social science, 15(3), 15-23.

Kotler, P., \& Keller, K. L. (2016). Marketing Management (15th ed.). New York: Pearson Education,Inc.

Laksmana, I. N. H., Kusuma, I. E. T., \& Landra, I. N. (2018). Effect of Customer Relationship Management on Customer Satisfaction and Loyalty at Pt. Harmoni Permata Gianyar, Bali. International Journal of Contemporary Research and Review, 9(03), 20610-20617. https://doi.org/10.15520/ijcrr/2018/9/03/470.

Pemayun, T. G. A. W. P., \& Seminari, N. K. (2020). The Role Customer Satisfaction Mediate The Effect Of Product Quality On Customer Loyalty. American Journal of Humanities and Social Sciences Research (AJHSSR), 4(6), 54-62.

Salah, M., \& Abou-Shouk, M. A. (2019). The effect of Customer Relationship Management (CRM) on customer loyalty. Journal of Tourism, Heritage \& Services Marketing, 5(2), 11-19. https://doi.org/=

Setyaleksana, B., Suharyono, S., \& Yulianto, E. (2017). Pengaruh customer relationship management $(\mathrm{crm})$ terhadap kepuasan dan loyalitas pelanggan (Survei pada Pelanggan GraPARI Telkomsel di Kota Malang). Jurnal Administrasi Bisnis S1 Universitas Brawijaya, 46(1), 45-51.

Siddiqi, T., Khan, K. A., \& Sharna, S. M. (2018). Impact of customer relationship management on customer loyalty: evidence from Bangladesh's banking industry. International Journal of Business, 
European Journal of Business and Management Research www.ejbmr.org

Economics and Law, 15(5), 92-101.

Suwandy, M. N., \& Setyari, N. P. W. (2020). Comparison of The ECommerce Transaction Value Relationship with Economic Growth in Indonesia and The United States. American Journal of Humanities and Social Sciences Research, 4(3), 1-07. www.ajhssr.com.

Tanisah, \& Maftukhah, I. (2016). The Effects of Service Quality, Customer Satisfaction, Trust, and Perceived Value towards Customer Loyalty. Jurnal Dinamika Manajemen, 6(1), 55-61.

Utami, I. G. A. A., \& Ekawati, N. W. (2020). The Role Of Customer Satisfaction Mediated Perception Of Value And Service Quality To Customer Loyalty. American Journal of Humanities and Social Sciences Research (AJHSSR), 4(2), 165-174.

Yudhanta, F. A., \& Widodo, T. (2018). Peran Kepuasan Pelanggan Dalam Memediasi Pengaruh Customer Relationship Management Dan Service Quality Terhadap Customer Retension (Studi Kasus Pengguna Smartphone Samsung Di Universitas Telkom). Journal of Chemical Information and Modeling, 5(3), 3274. 